\title{
Armed On-board Protection of Italian Ships: From an Apparent Hybrid Model to a Regulated Rise of Private Contractors
}

\author{
Giorgia Bevilacqua*
}

\begin{abstract}
The sharp increase of piracy attacks in the last two decades was followed by a parallel increase of demand in the maritime security sector. A plenty of flag States around the world have started to authorize the deployment of armed security guards, either military or private, aboard commercial ships. In 2011, Italy also introduced the possibility of embarking armed security services to protect Italian flagged ships sailing in dangerous international waters. Like the other flag States' legal systems, the newly adopted Italian legislation aims to preserve the domestic shipping industry which was particularly disrupted by modern-day pirates. On the other hand, the doubling of approaches of the Italian legal and regulatory framework, initially privileging military personnel and then opting for the private solution, took the author to investigate the main relevant features of the Italian model of regulation and to analyze the recent developments of the domestic legal practice on counterpiracy armed security services, focusing on the role that customary and treaty obligations of international law played for the realization at national level of on-board armed protection of Italian ships. The use of lethal force at sea and the relationship between the shipmaster and the security guards will receive specific attention in this article.
\end{abstract}

Keywords: maritime security services, Italian hybrid system, Military and Private Personnel, Use of force, relation with the shipmaster

\section{Introduction}

The significant impact of piracy ${ }^{1}$ and armed robbery at sea $^{2}$ on global shipping brought the international com-

Researcher at the Università degli Studi della Campania Luigi Vanvitelli.

1. On the definition of maritime piracy, see Arts. 14-22 of the High Seas Convention, done at Geneva on 29 April 1958, entered into force on 30 September 1962 (UN, Treaty Series, Vol. 450) and Arts. 100-110 of the United Nations Convention on the Law of (UNCLOS) done on 10 December 1982, entered into force on 16 November 1994 (UN, Treaty Series, Vol. 1833).

2. For the definition of armed robbery at sea, see Art. 2.2 of the Draft Code of Practice for the Investigation of the Crimes of Piracy and Armed Robbery against Ships, approved by the Committee on Maritime Security on 20 December 2000, MSC/Circ. 984 (subsequently adopted by the IMO Assembly on 29 November 2001, with Resolution A.922(22). munity to promote a range of different measures to tackle them. In response to several resolutions by the United Nation Security Council (UNSC) ${ }^{3}$ since 2008, states - unilaterally and through international organisations - focused most of their efforts on the militarisation of pirate-ridden waters. ${ }^{4}$ As is well-known, however, such measures are extremely expensive, and the vast areas in which pirates operate have created a sort of security gap that prevents navies from defending every commercial ship which sails in dangerous waters. Furthermore, while for hijackings off the coast of Somalia, the UNSC has authorised and repeatedly renewed its authorisation to use 'all necessary means to repress acts of piracy and armed robbery', 5 analogous instruments under Chapter VII of the UN Charter in order to counter these criminal phenomena in other regions of the world have not been approved so far.

The limits of international naval patrols led shipowners to rely on alternative security options in defending their vessels and seafarers against violence at sea. As a matter of fact, the sharp increase of pirate attacks was quickly followed by a parallel increase of demand for security. While floating armories full of arms for hire against criminality at sea became more and more common, shipowners could soon rely on a variety of models of contracted maritime security services. ${ }^{6}$

In parallel, aware of growing developments in the security sector, a plenty of flag states around the world started to authorise the deployment of armed guards, either

3. For instance, see UNSC Resolution 1846 (2008) on Somalia, adopted at its 6026th meeting, on 2 December 2008, UN Doc. S/RES/1846 (2008), para. 9 .

4. The most prominent coalitions of forces which have operated against piracy are the NATO Operation Ocean Shield, the European Union Naval Force - Operation Atalanta, Combined Task Force 151 and Malacca Strait Patrols. National counter-piracy missions were also active, such as China, India, Japan, Malaysia, Russia, Saudi Arabia, South Korea, Yemen. More recently, 'TSARE Teku', the Nugeruan antipiracy operation was launched to patrol the Gulf of Guinea.

5. For the first authorisation to enter and intervene in Somali waters, see: UN Security Council, Resolution 1816 (2008) on Somalia, adopted on 2 June 2008, UN Doc. S/RES/1816 (2008). With the subsequent Resolution 1851 (2008), the authorisation was further extended to certain parts of the Somali coasts. Regarding the temporary extension of the authorisation, see, ultimately, Resolution 2316 (2016), adopted on 9 November 2016, UN Doc. S/RES/2316 (2016) (2016).

6. See 'Oceans Beyond Piracy, Defining Contracted Maritime Security', 16 December 2016. Available at: http://oceansbeyondpiracy.org/sites/ default/files/attachments/DefiningContractedSecuritylssuePaper0921 16.pdf (last visited 3 January 2019). 
military or private, aboard civilian ships. The first relevant step was undertaken by four of the world's largest ship registries - Panama, the Bahamas, Liberia, and the Marshall Islands - when they presented the 'New York Declaration' during the Contact Group plenary session in May 2009. Shortly afterwards, other states around the world, including the United States of America, Japan, Cyprus and Singapore also signed this declaration and promulgated guidelines and recommendations providing new measures to ensure secure navigation in international waters. ${ }^{7}$ Regarding European states, the majority of them, such as Denmark, ${ }^{8}$ Germany, ${ }^{9}$ Greece, the United Kingdom (UK) and the Scandinavian countries allowed for the boarding of private security guards. Few other states, such as the Netherlands ${ }^{10}$ and France are on the way to introducing or have already introduced vessel protection systems based on the boarding of military personnel only.

In 2011, Italy also introduced the possibility of embarking armed security services to protect civilian ships sailing in dangerous waters. Like the other flag states' legal systems, the newly adopted Italian legislation aims to preserve the domestic shipping industry which was particularly disrupted by modern pirates. Of note, Italy is one of those states which has well-defined economic interests that need protection from piracy and armed robbery. Italy has a long-standing maritime tradition and most of its foreign trade, both for import and export, is based on transport by sea. The International Chamber of Shipping places Italy at the fifth place in Europe - after Malta, Greece, Cyprus, and the UK and includes it among the world's major shipping flags. 11

Since the resurgence of piracy, its traditional national fleet has been heavily threatened by piracy attacks. As reported to the International Maritime Bureau (IMB), approximately thirty-four Italian vessels were hijacked by pirates when such criminal phenomenon reached its peak between 2008 and $2012 .{ }^{12}$ With specific respect to 2011 - when the new Italian antipiracy legislation was

7. For a comparison of some flag state approaches on armed security services, see E. Cusumano and S. Ruzza, 'Security Privatization at Sea: Piracy and the Commercialisation of Vessel Protection', International Relations 1 (2017); Y.M. Dutton, 'Gunslingers on the High Seas: A Call for Regulation', Duke Journal of Comparative \& International Law 105 (2014); J. Kraska, 'International and Comparative Regulation of Private Maritime Security Companies Employed in Counter-Piracy', in D. Guilfoyle (ed.), Modern High Seas Piracy (2013) 219.

8. On the Danish model of regulation, on this special issue of the Erasmus Law Review, see C. Frier.

9. On the German model of regulation, on this special issue of the Erasmus Law Review, see T. R. Salomon.

10. On the Dutch model of regulation, on this special issue of the Erasmus Law Review, see P. Mecies and S. Eckhardt.

11. The statistics of the International Chamber of Shipping are available at: www.ics-shipping.org/shipping-facts/shipping-and-world-trade/theworld's-major-shipping-flags (last visited 3 January 2019). Similarly, the International Maritime Organisation (IMO) includes Italy in the list of top twenty leading merchant fleets. See IMO Maritime Knowledge Centre, International Shipping Facts and Figures - Information Resources on Trade, Safety, Security, Environment, 6 March 2012.

12. See the IMB Report on acts of piracy and armed robbery against ships for the period 1 January - 31 December 2012, January 2013. adopted - well eight Italian ships were hijacked. ${ }^{13}$ Some of these criminal episodes had a particularly strong impact on Italian shipping companies, in terms of both economic and human costs. On the one hand, piracy has determined a sharp increase of costs due to rerouting, fuel and insurance premiums and, additionally, when the vessel was effectively seized by pirates, they have prevented the shipowner from making use of the vessel for commercial purposes during the period of the seizure. On the other hand, crew members embarked on seized vessels belonging to Italian shipping companies have been held at the hands of violent pirates for days, weeks and sometimes also months.

At the same time, the well-known incident regarding two Italian military members of a vessel protection detachment (VPD), on board the Italian oil tanker Enrica Lexie, accused of killing two Indian seamen off the coast of Kerala (India) have drawn the attention of the public to the challenges related to the use of military services on board private ships; ${ }^{14}$ an event that posed a number of serious legal and practical issues that underline the importance to stipulate accurate rules to govern the use of force at sea and which in practice lead Italy to move towards private security services.

In light of this complex and still evolving background, the purpose of this article is to illustrate and analyse the main characteristics of the Italian model of regulation and investigate the role that customary and treaty obligations of international law played for the implementation at national level of on board armed security services. For this purpose, we will initially explore the legal and institutional context in which the new Italian model of regulation was conceived, having a look at the different initiatives considered to protect the freedom of navigation of the national fleet in pirate-prone hot spots (Section 2). Even though an Italian model of regulation on armed security services was adopted in 2011, this model was soon amended and integrated with a number of subsequent acts. We will therefore illustrate and analyse the main relevant aspects of this articulated framework, highlighting the doubling of approaches of the Italian decision-makers, initially in favour of the military option and only four years later in favour of the private one (Section 3). Against the Italian final preference for private guards, what assumes key relevance is an assessment of the regulatory framework, establishing whether and under what conditions security personnel may be armed and used on board Italian vessels and which relationship may be established between the security personnel and the shipmaster (Section 4). Finally, we will conclude by outlining the strong and weak points of the new legal practice, envisioning a pos-

13. Ibid.

14. On the Enrica Lexie's case, see D. Guilfoyle, 'Shooting Fisherman Mistaken for Pirates: Jurisprudence, Immunity and State Responsibility', European Journal of International Law: Talk!, 2 March 2012, available at: www.ejiltalk.org (last visited 3 January 2019); Kraska, above n. 7; N. Ronzitti, 'The Enrica Lexie Incident: Law of the Sea and Immunity of State Officials Issues', 22 The Italian Yearbook of International Law 3 (2012) 
sible way forward to fill the existing maritime security gap (Section 5).

\section{Development towards the Italian Model}

To protect the national shipping industry, Italian authorities have soon decided to undertake different counter-piracy initiatives.

First of all, the Italian Navy has intensively contributed to the militarisation of the waters off the coast of Somalia, participating to several multinational antipiracy operations, such as the NATO 'Operation Ocean Shield' 15 and the European Union (EU) 'Operation Atalanta'. ${ }^{16}$ On 11 October 2011, for example, the crew (including six Italian members) which retreated into the citadel of the Italian bulk carrier Montecristo was freed, thanks to the prompt intervention of a NATO naval team. $^{17}$

Secondly, rather than contributing to the attractive and quite common practice of the catch and release, ${ }^{18}$ Italy has occasionally prosecuted suspected pirates captured at sea by naval forces. On this basis, the alleged criminals were transferred before Italian courts and prosecuted pursuant to both the international customary principle of universal jurisdiction ${ }^{19}$ and the applicable national legal system. The latter includes the provisions set forth in the Italian Navigation Code (codice della navigazione $)^{20}$ and a more recent Law-Decree, offering a special legal framework for the apprehension and detention

15. Following the previous NATO's 'Operations Allied Provider' and 'Allied Protector', 'Operation Ocean Shield' began on 17 August 2009 and ended on 15 December 2016. It adopted a comprehensive approach to counter-piracy efforts and focused on operations at sea but also assisted regional states, at their request, to develop counter-piracy operations and capacity. Further information on 'Operation Ocean Shield' are available at: https://www.mc.nato.int/missions/operation-oceanshield.aspx (last visited 3 January 2019).

16. EUNAVFOR Operation Atalanta was the first European counter-piracy naval mission launched on 8 December 2008 in support of UNSC Resolutions $1814,1816,1838$, and 1846. Its mandate was reputedly extended. The last extension concerned the period from January to December 2017. See Council Decision (CFSP) 2016/2082 of 28 November 2016 amending Joint Action 2008/851/CFSP on a European Union military operation to contribute to the deterrence, prevention and repression of acts of piracy and armed robbery off the Somali coast, in Official Journal of the European Union L 321/53, 29 November 2016. Further information on EUNAVFOR Atalanta are available at: http:// eunavfor.eu (last visited 3 January 2019).

17. See the IMB Report on acts of piracy and armed robbery against ships for the period 1 January - 31 December 2011, January 2012. Available at: www.rk-marine-kiel.de/files/piraterie/imb/imb_piracy_report_2010. pdf (last visited 3 January 2019).

18. On catch and release, see The Report of the of the Secretary-General pursuant to Security Council resolution 1950 (2010), adopted on 25 October 2011, UN Doc. S/2011/662.

19. On the principle of universal jurisdiction, see Arts. 19 of the High Seas Convention and Art. 105 of the UNCLOS. For doctrine, M.H. Nordquist, S. Nandan \& S. Rosenne (eds.), 3 United Nations Convention on the Law of the Sea 1982: A Commentary, (1995), at 212; K.C. Randall, Universal Jurisdiction Under International Law, 66 Tex. L. Rev. 785 , 840 (1988).

20. See Arts. 1135 and 1136 of the Italian Navigation Code. of suspected pirates when the Italian state or Italian citizens or Italian goods are or risk being damaged. ${ }^{21}$ For the first time since the upsurge of contemporary pira$\mathrm{cy},{ }^{22}$ the Italian Supreme Court of Cassation has recently condemned Somali citizens to eight years of imprisonment with the accusation of maritime piracy and other related illicit acts. ${ }^{23}$

Notwithstanding the Italian efforts in terms of enforcement jurisdiction at sea and adjudicative criminal jurisdiction before national courts, Italian interests were not always sufficiently protected. In many other cases, Italian vessels were boarded, seized and finally released only after long periods of time and large ransoms were paid. For instance, the Italian flag oil tanker $M V$ Savina Caylin, which was hijacked off the coast of Somalia by five pirates in skiffs armed with automatic weapons on 8 February 2011, was released only after more than ten months of cruel detention of the crew members and after than 10 million USD were paid. ${ }^{24}$ Among the several Italian ships seized by pirates in the same year, it is believed that the bulk carrier Rosalia D'Amato and the chemical tanker Enrico Ievoli as well were freed only after a ransom was paid either by the flag state or by the shipping company. ${ }^{25}$

Further to these and other incidents which underlined the existence of a real security gap for the Italian fleet navigating off the Horn of Africa region, private shipowners have strongly been advocating - mainly through the principal Italian association of ship owners' representatives (Confitarma) - the adoption of additional instruments to protect their vessels and seafarers. The attention of the shipping industry was especially drawn to armed security services; they seemed to be particularly successful in acting as an actual deterrent and consequently useful in reducing the risk to the lives and wellbeing of those on board targeted ships. Specifically, this debate was focused on how best to manage armed secur-

21. See Decree Law No. 209 of 30 December 2008, converted with amendments in Law No. 12 of 24 February 2009, concerning Extension of Time of Interventions for Development Cooperation, Support of Peace and Stabilization Processes, and Participation of Armed and Police Forces in International Missions. For doctrine on domestic antipiracy systems, see M. Bo, 'Piracy at the Intersection between International and National: Regional Enforcement of a Transnational Crime', in H. van den Will and C. Paulussen (eds.), Legal Responses to Transnationa and International Crimes - Toeards an Integrative Approach, (2017) 71 , at 83.

22. A previous case was closed through a plea bargain between the public prosecutor and all defendants, arrived up to a first instance judgment, when on 4 December 2012 the Tribunal of Rome sentenced eleven Somali citizens to three and half years of imprisonment for the attempted hijacking of the Italian tanker Valdarno. This judgment was not published, but some comments are reported in the Maritime Security Review. Available at: www.marsecreview.com (last visited 3 January 2019).

23. Court of Cassation (Section II, pemal), 20 June 2013, No. 26825, which confirms the first and second instance decisions (see Juvenile Tribunal of Rome, 16 June 2012 and the Court of Appeal, Juvenile Section, 6 October 2012).

24. Somalia Report. 2011, MV Savina Caylyn Released by Somali Pirates, 21 December. Available at: http://piracyreport.com/index.php/post/ 2240/MV_Savina_Caylyn_Released_by_Somali_Pirates (last visited 3 January 2019).

25. IMB Annual report for 2011, above n. 17 
ity services on board private commercial ships transiting through high risk piracy zones.

The first option considered by Italian authorities is the military one. In February 2011, the chief of the Italian Navy (Capo di Stato Maggiore) received a mandate from the Ministry of Defense to set up an ad hoc technical panel entitled to analyse all operative and legal challenges related to the possible deployment of VPDs on Italian civilian vessels. This panel - including a delegation of the Ministry of Defense and other concerned ministries as well as representatives of Confitarma and other private stakeholders - elaborated an articulated normative proposal on the use of uniformed personnel. Subsequently both options - the private and the military one - were further examined by the Defense Commission of the Senate ( $I V$ Commissione permanente) which carried out a survey of the main self-protection measures adopted by other European member states ${ }^{26}$ and interviewed the chief of the Italian Navy on the topic. ${ }^{27}$

From this lively debate emerged a clear preference for the military option. Uniformed personnel were considered highly qualified, well trained and equipped. Differently from private personnel, they could also rely on weapons of war and very modern technologies. Furthermore, military teams can act under the direct control of national public authorities and in cooperation with the above-mentioned naval units operating in high risk areas. From a strictly legal perspective, the public security model could be enforced in a safer and faster manner since it was already based on existing procedures and rules of engagement. An additional argument in favour of the state representatives' option is mentioned by the chief of the Italian Navy: military personnel is in line with the EU military approach. Namely, the first EU antipiracy naval 'Operation 'Atalanta' aims, among other things, to 'provide protection to vessels chartered by the World Food Programme, including by means of the presence on board those vessels of armed units' ${ }^{28}$

Meanwhile, while the debate was pending among the different categories of stakeholders, the Italian legal system was completely lacking an adequate security model of regulation. In the absence of a formal decision authorising the use of armed guards aboard national private vessels, Italian shipowners had started to rely on flags of convenience, that is, on the flag of those states

26. See Fourth Permanent Commission - Defense, Resolution on the possible deployment of VPDs on board Italian civil vessels transiting international waters under risk of maritime piracy, 22 June 2011, p. 7. A draft of regulation was prepared on 3 March 2010 and presented to the Italian Parliament with the aim to allow private security services (Senate of the Italian Republic, Draft regulation presented on the initiative of Amato e Catoni, No. 2050. Adde drafts No. 2092, submitted by Senatore Enrico Musso and others No. C 3321).

27. The interview of the chief of the Italian Navy held on 15 June 2011 is available at: www.senato.it/documenti/repository/commissioni/comm 04/documenti_acquisiti/Intervento\%20amm.\%20sq. \%20Branciforte. pdf (last visited 3 January 2019).

28. See Council Decision 2012/174/CFSP of 23 March 2012 amending Joint Action 2008/851/CFSP on a European Union military operation to contribute to the deterrence, prevention and repression of acts of piracy and armed robbery off the Somali coast, Official Journal of the European Union L 89/69, 27 March 2012. that already had a more convenient framework in force that allowed for the deployment of armed security personnel on board. ${ }^{29}$ For instance, a flag of convenience was particularly useful in avoiding the risk of falling prey to pirates off the coast of the Seychelles on 26 April 2009, when pirates attacked the cruise ship MSC Melo$\mathrm{dy}$, belonging to an Italian company but sailing under a Panama flag, and were repelled thanks to an Israeli security team placed on board. ${ }^{30}$

\section{Key Aspects of the Regulation}

The pressure of Italian shipowners and the aggressive competition of the more secure foreign flag vessels led to an acceleration of the legislative process. Since 6 August 2011, the Law-Decree No. 107/2011, as amended by Law 2 August 2011 No. 130, was turned into law and definitely enforced. ${ }^{31}$

On paper, Law 130 has a very wide scope. On the one hand, it extends the participation of the Italian armed and police forces to some international missions and to deployment cooperation, peace support and stabilisation processes until 31 December 2011, while on the other hand, it comprises several provisions on the implementation of UNSC Resolutions on Libya and on international efforts to fight maritime piracy. ${ }^{32}$

As far as counter-piracy armed services are concerned, the relevant provisions are all stipulated in Article 5, which introduced an hybrid model of regulation authorising private shipowners to embark VPDs (nuclei militari di protezione) or, alternatively, private security guards (guardie particolari giurate) on board Italian ships navigating across dangerous international waters. ${ }^{33}$ The rationale of Article 5 - titled 'Further Counterpiracy Measures' - is to provide Italian merchant vessels with

29. On the issues related to the use of flags of convenience, see L. Schiano di Pepe, 'La questione della nazionalità delle navi dinanzi al tribunale internazionale per il diritto del mare', Rivista di diritto internazionale 329 (2002).

30. Information available at: http://news.bbc.co.uk/2/hi/africa/ 8019084.stm (last visited 3 January 2019).

31. Law No. 130 of 2 August 2011 (Italian Official Journal No. 181 of 5 August 2011). Enactment as a Law, with amendments, of Decree Law No. 107 of 12 July 2011, concerning the extension of the intervention of development cooperation, support of peace and stabilisation processes, international missions of the Armed and Police Forces, as well as the implementation of UNSC Resolutions 1970 (2011) and 1973 (2011). Urgent measures against piracy.

32. See G. Rubagotti, 'Use of Force and Peace keeping', 21 The Italian Yearbook of International Law 428 (2011).

33. For a thorough analysis of the Italian legislation introducing the possibility to embark armed services on board, see G. Bevilacqua, 'Counter Piracy Armed Services, the Italian System and the Search for Clarity on the Use of Force at Sea, 22 The Italian Yearbook of International Law 39 (2012); E. Cusumano, S. Ruzza, 'Contractors as a Second Best Option: The Italian Hybrid Approach to Maritime Securit', Ocean Development \& International Law 111 (2015); N. Ronzitti, ‘Un passo avanti per la tutela delle navi italiane ma troppa cautela nella legge di conversione', Guida al diritto 54 (2011); M. Tondini, 'Impiego di NMP e guardie giurate in funzione antipirateria', Rivista marittima 32 (2013). 
more freedom of navigation while crossing pirate-ridden waters. In this sense, this provision gives execution in the Italian legal system to the customary principle of international law codified in Article 87 of the UN Convention on the Law of the Sea (UNCLOS) which stipulates that the high seas shall be open to ships of all states, whether coastal or landlocked. Of the freedoms pertaining to the high seas, the main one is the freedom of navigation. ${ }^{34}$ It is clear that pirates, when boarding and hijacking private ships, are preventing the concrete realisation of the freedom of navigation on the high seas. Allegedly, by means of maritime security services, the Italian legislator attempts to increase the freedom of navigation of Italian flag vessels.

In brief, the adoption of Article 5 of Law 130 represents a first important step forward in the management of Italian maritime security services. In the modern era of piracy, it is the first time that private ships flying Italian flags are allowed under Italian law to embark security personnel for defense purposes. At the same time, the Italian hybrid on board protection model is destined to become a single component of a broader and dynamic legal and regulatory framework. In the following subsections, we will first analyse the general content of the main relevant provisions stipulated in Article 5 of Law 130 (Section 3.1) and will then verify how these provisions were subsequently amended and integrated by further implementing regulations, governing some specific aspects on the deployment of maritime security services (Section 3.2).

\subsection{Article 5 of Law $\mathbf{1 3 0}$}

Originally, the Italian on board protection model comprised of two main groups of provisions: the first group addressed to VPDs (Art. 5, paras. 1-3), which was abrogated in $2015,{ }^{35}$ and the other group addressed to private guards (Art. 5, paras. 4, 5, 5-bis and 5-ter) which is still in force and applicable.

Regarding VPDs, this category of contracted security service is quite unique in the maritime security field. In practice, the deployment of VPDs introduced military personnel, equipment, and activities, including militaryspecific command and control hierarchies, into the shipping sector, aboard private vessels. ${ }^{36}$ More recently, the Code of conduct adopted by the Italian Ministry of Interior for Non-governmental Search and Rescue Organizations (NGOs) appears like an attempt to replicate this figure in a different context. In short, the Italian Code of conduct requires, among other things, to deploy Italian police officers on board NGOs' rescuing vessels with the specific aim to counter migrant smuggling and/or human trafficking in the Mediterranean Sea. Despite antipiracy VPDs, the newly proposed Ital-

34. See Art. 87(1)(a) UNCLOS.

35. Decree-Law No. 7 of 18 February 2015 on urgent measures to counter national and international terrorism, as converted, with amendments, by Law No. 43 of 17 April 2015

36. An Italian version of the Italian Code of conduct for NGOs engaged in Search and Rescue operations in the Mediterranean sea is available Interior at: www.interno.gov.it/sites/default/files/codice_condotta_ong. pdf (last visited 12 June 2018). ian police officers should be embarked on NGOs' vessels also when they sail a foreign flag. But Italy, like any other coastal state, is normally not entitled to exercise any enforcement power over ships flying other countries' flags when they navigate on the high seas. Therefore, this and other requirements of this Code of conduct, faced several criticisms from NGOs - namely, some of them have refused to sign it - but also from the international legal and political doctrine, ${ }^{37}$ which especially highlights the risk that Italian officers operating on NGO's ships in dangerous international waters offshore from Libya might be exposed to retaliation by smugglers and militias.

Regarding the specific functioning of all antipiracy VPDs, their operations were directly coordinated by the chief of the Italian Navy, to which all requests of protection had to be addressed. ${ }^{38}$ Each military team had to consist of a leader and additional members of the Italian Navy or other national military forces. For instance, the six military officers embarked on the Italian tanker Enrica Lexie during the incident mentioned earlier off the coast of Kerala were members of the regiment 'San Marco', which is an infantry military unit belonging to the Italian Navy. Despite the presence on board of VPDs, the vessel itself remained a private vessel as it did not belong to the armed forces of the state and lacked the markings identifying it as being on government service. $^{39}$

Before Italian provisions governing VPDs services were abrogated in $2015,{ }^{40}$ if the military team was available, it was embarked in the identified port at the agreed time. On the contrary, if the military team was not available, shipowners could also rely on privately contracted armed security personnel.

Military and private services were subject to certain common general rules stipulated in the Italian on board protection model. For example, both could be embarked only on board vessels flying the Italian flag. As a consequence, Italian vessels flying foreign flags do not fall within the scope of Article 5. Furthermore, the ship embarking with military or private teams should navigate in specific unsecure zones of the high seas, identified as the 'High Risk Area'. Yet, in both circumstances, the heavy costs of military or private guards should be

On the legality of the Italian Code of conduct for NGOs, see E. Cusumano, 'Traightjacketing Migrant Rescuers? The Code of Conduct on Maritime NGOs', Mditerranean Politics (2017). Available at: https:// www.tandfonline.com/doi/full/10.1080/13629395.2017.1381400 (last visited 3 January 2019); M. Fink and K. Gombeer, 'Non-Governmental Organisations and Search and Rescue at Sea', Maritime Safety and Security Law Journal (2018), available at: www.marsafelawjournal.org/ wp-content/uploads/2018/06/MarSafeLaw-Journal_Issue-4_Gombeerand-Fink.pdf; V. Moreno-Lax (last visited 3 January 2019), 'Nonsensical', 'Dishonest', Illegal: the 'Code of Conduct', interview of 24 July 2017, available at: https://sea-watch.org/en/nonsensical-dishonestillegal-the-code-of-conduct (last visited 3 January 2019); M. Ramacciotti, 'Sulla utilità di un codice di condotta per le organizzazioni non governative impegnate in attività di search and rescue (SAR)', Rivista di diritto internazionale 213 (2018).

38. See Law 130, Art. 5, para. 1.

39. See Art. 8 of the High Seas Convention and Art. 29 of the UNCLOS

40. See supra note 35 . 
borne by shipowners. According to Article 5, paragraph 6-ter their deployment could not lead to any additional burdens on the state. ${ }^{41}$ Last but not least, both military and private teams can act only to protect the ship from possible piracy attacks. Namely, when aboard private ships, neither military nor private personnel can hunt suspected pirates. This prohibition is made descending from international customary and treaty law, as codified by both Article 21 of the High Seas Convention and Article 107 of the UNCLOS, which entrust the function of policing the seas only to warships and other vessels clearly marked and identifiable as government units. In other words, according to these provisions, only military and governmental ships have the power to seize a pirate ship, arrest the persons and seize the property on board. ${ }^{42}$

Notwithstanding these general common aspects, uniformed and private security guards are subject to different specific rules. First of all, pursuant to the Italian onboard protection model, while VPDs are subject to the already existing rules of engagement issued by the Ministry of Defense, private security guards shall operate on board according to the national legislation regulating the use of private security services on Italian territory. ${ }^{43}$ In Italy, the general provisions applicable to private security personnel and companies are stipulated in the Italian Code of Public Security, which is explicitly recalled in the Italian on-board protection model. ${ }^{44}$ According to this Code, public and private entities can rely on private guards for the surveillance and custody of movable and immovable properties. To operate in the Italian territory, private guards shall comply with certain subjective requirements (e.g. have a clean criminal record and have attended specific trainings) and obtain a specific authorisation from the Interior Ministry officials (Prefetti). In addition, under this Code, for the carrying of weapons a specific license of the Ministry of Interior is also needed. ${ }^{45}$ Finally, bearing in mind that private ships having security personnel on board cannot policy the seas, the protection that can be ensured by private guards is actually limited. In accordance with the Italian Code of Public Security and the Criminal Code, private guards can act only in defense of goods and property within the frame of the legitimate defense, provided for in Article 52 of the Criminal Code. Differently, VPDs can use the lethal force for the purpose of protecting

41. See Law 130, Art. 5, paras. 4, 5, 5-bis and 5-ter.

42. Customary international law - as codified by both Art. 21 of the High Seas Convention and Art. 107 of the UNCLOS, entrusts the function of policing the seas only to warships and other vessels clearly marked and identifiable as government units.

43. See Arts. 133, 134 and 138 of the Italian Code of Public Security (Testo unico delle leggi di pubblica sicurezza), included in the Royal-Decree of 18 June 1931, No. 773, and following amendments, and Art. 249 and ff. of the related implementing Regulation, included in the RoyalDecree of 6 May 1940, No. 635, and following amendments. These rules are expressly recalled in Law 130, at Art. 5, para. 4.

44. See Italian Code of Public Security.

45. Ibid. vessels and crews in accordance with the Peacetime Military Criminal Code. ${ }^{46}$

\subsection{The Implementing Regulations of the Italian} On-board Protection Model

To make Article 5's provisions concretely enforceable, Italian decision-makers had to issue further implementing regulations. Some of them were rapidly adopted. In this sense, on 1 September 2011, the Italian Ministry of Defense adopted Decree No. 55447, ${ }^{47}$ in order to identify specific areas in international waters at risk of piracy in line with the International Maritime Organisation (IMO) periodical reports concerning the so-called High Risk Area. ${ }^{48}$ Likewise, on 11 October 2011, the Ministry of Defense and Confitarma entered into a memorandum of understanding (protocollo di intesa) specifying the modalities used to protect national vessels. ${ }^{49}$

Other implementing regulations including rules on the deployment of private guards, instead, have needed much longer before being introduced and definitely enforced. In particular, in order to be embarked on board merchant ships at risk of piracy, Italian private guards must observe the rules listed in an ad hoc decree issued by the Ministry of Interior, specifically aimed to clarify the relationship between the private guards and the shipmaster on the one hand, and to regulate the use, the type, the quantity, and the storage of weapons on the other hand. ${ }^{50}$ And, although such Ministerial Decree was to have been adopted within sixty days from the entry into force of Law $130,{ }^{51}$ the deployment of private contractors was not possible before October 2013 because of an incomplete regulatory framework. ${ }^{52}$

As a matter of fact, the implementing Decree was definitely drafted in December 2012 and entered into force only in March 2013 (hereinafter the Implementing Ministerial Decree). ${ }^{53}$ And, even though this Decree is expressly aimed to define the implementing modalities

46. In this respect, see N. Ronzitti, 'La difesa contro i pirati e l'imbarco di personale militare armato sui mercantili: il caso della "Enrica Lexie" e la controversia Italia-India', Rivista di diritto internazionale 1073 (2013).

47. See Decree of the Ministry of Defense No. 55447, of 1st September 2011 (Italian Official Journal No. 212, of 12 September 2011). Identification of the international area at risk of maritime piracy where VPDs can be embarked. On 24 September 2015, the Ministry of Defense adopted a new implementing Decree in line with the newly introduced IMO Circular including the revision to coordinates of the High Risk Area, (Italian Official Journal No. 232 of 6 October 2015.

48. The current High Risk Area is defined by the IMO Circular No. 3606 of 2 December 2015. Available at: www.imo.org/en/OurWork/Security/ PiracyArmedRobbery/Guidance/Documents/Circular\%20Letter\%20No. 3606.pdf (last visited 3 January 2019).

49. Memorandum of understanding (protocollo di intesa) between the Ministry of Defense and Confitarma adopted on 11 October 2011 aimed to agree the modalities to protect national vessels.

50. See Law 130, Art. 5, para. 5-ter.

51. Ibid.

52. Meanwhile, however, pursuant to a Law-Decree of 29 December 2011, the Italian Government has authorised their deployment for a temporary period, notwithstanding the absence of rules on the use of force and weapons by private guards, provided that they have taken part in international missions of the Italian Armed Forces for at least 6 months. See Law-Decree 29 December 2011, No. 215, as by Law 24 February 2012, No. 13 (GU 27 February 2012).

53. See Ministerial Decree. 
stipulated in the Italian on-board protection model, ${ }^{54}$ its adoption may not be considered the final step of the legislative process. In light of persisting uncertainties about the procedure required for the authorisation of private guards aboard, it was necessary the adoption of yet another implementing act, that is, a memorandum signed by the chief of the Italian police. This memorandum contains all the provisions ensuring a consistent interpretation of counter-piracy regulations by the Interior Ministry officials responsible for authorising the activities of domestic private security companies. Finally, the use of private guards became legally possible only after the memorandum was released in October 2013, and thus, more than two years later from the Law 130 entering into force.

The prima facie specificity of the Italian legal and regulatory system on counter-piracy armed security services is to allow the use of both military and private teams. Our analysis, however, shows that for improving the freedom of navigation of Italian flagships in pirateprone hot spots, national authorities have first opted for VPDs and have only afterwards turned to private guards. Indeed, the (apparent) hybrid approach introduced between 2011 and 2015 could apply only on paper for a long time. As seen earlier, the implanting regulations necessary to deploy private security contractors were definitely adopted only in October 2013. In addition, the deployment of private guards remained only a second-best option. Notwithstanding the adoption of the implementing acts, private personnel could be embarked only if VPDs were not available and, as we will see in detail in the subsequent section (Section 4), only if certain essential requirements - regarding the vessel and the security team itself - were met.

On the other hand, VPDs' provisions set forth in the Italian on-board protection model had an intense but rather short history. A number of changes in the international and national sphere - such as the decrease of piracy in the Horn of Africa region, the problematic implications of the ongoing dispute between India and Italy on the Enrica Lexie's incident, as well as the shifting priorities of the Italian military forces - led Italian authorities to abandon the NATO Operation 'Ocean Shield' and amend Article 5 of Law 130 with the abrogation of the group of provisions governing VPDs. ${ }^{55}$ As a result, as of 2015, the only available option for armed protection on Italian vessels crossing the High Risk Area consists in using private contractors.

54. See Ministerial Decree, Art. 1.

55. See Decree-Law No. 7 of 18 February 2015 on urgent measures to counter national and international terrorism, as converted, with amendments, by Law No. 43 of 17 April 2015.

\section{Use of Force and the Relation between the Master and the Guards/Team Leader}

Several important aspects establishing rules on the use of force and governing the relation between the shipmaster and private guards were fully clarified or newly introduced only at the end of 2013 by means of the aforementioned body of implementing regulations descending from Article 5 of Law 130. In effect, the adoption of these implementing regulations represents a significant outcome, especially in terms of legal certainty for maritime operators. The absence in Italy, up to the end of 2013, of an accurate regulatory framework gave rise to a problematic security gap. Rather than only a theoretical matter, this absence has de facto prevented the use of private personnel on Italian flagships for about three years. Whereas other flag $\operatorname{states}^{56}$ had already enacted specific legislations which set forth provisions on the use of force and the relation between the master and the guards, Italian maritime operators could eventually rely on recommendations and guidelines developed by international shipping associations. ${ }^{57}$ Of such soft-law measures, the IMB's Best Management Practices (BMP) for Protection against Somalia Based Piracy $^{58}$ developed by industry bodies, along with national navies, played a role of the outmost relevance in informing Italian shipowners on useful tools to improve the safety and security of their merchant vessels against acts of piracy. And indeed, even if not mandatory, the importance of complying with the BMPs has been later recalled in the Italian implementing regulations. On the other hand, in light of their legal nature the BMPs were certainly not able to give implementation to Law 130 and to enable maritime operators to embark private guards on Italian ships navigating in dangerous international seas.

In order to analyse the articulated Italian regulatory framework, we will first deal with these provisions governing the use of private force, focusing on a number of supplementary requirements about whether and under what conditions contractors can be armed, with what kind of weapons they can be armed, and when and how such weapons may be lawfully embarked and eventually used (Section 4.1), and secondly, we will pass on the relation between the shipmaster and the guards, pointing out the differences on the relation with the military team (Section 4.2).

56. See, e.g. Panama, the United States, Spain and the UK.

57. See, for instance, BIMCO; the largest international shipping association, has detailed standard contract for the employment of security guards on vessels (GUARDCON). See also Industry Guidelines for the Use of Private Security Contractors May 2011.

58. Available at: http://eunavfor.eu/wp-content/uploads/2013/01/bmp4low-res_sept_5_20111.pdf (last visited 3 January 2019). 


\subsection{The Use of Private Force}

The Implementing Ministerial Decree clarifies that private contractors in Italy can be either directly hired by the shipowner concerned or employed by a private military and security company (PMSC). ${ }^{59}$ Beginning from this distinction, the Decree clarifies that a team of private contractors shall include at least four members. They shall have a special license for carrying long guns for personal defense; they shall have work experience in Italian armed forces, also as volunteers; or they shall have attended a course organised by the Ministries of Interior, Defense, and Transports. ${ }^{60}$ Personnel who served in the armed forces and have participated for at least six months in international operations, however, can be exempted from the obligation to attend and pass any course until the possibility for additional compulsory training will be provided. ${ }^{61}$ In addition, the Implementing Ministerial Decree stipulates that shipowners can also employ foreign contractors. In order to operate as maritime security providers on Italian flag vessels, foreign guards have to be established in another EU member state and receive a specific authorisation from the Italian Ministry of Interior. ${ }^{62}$

A set of detailed provisions is also addressed to PMSC. Each PMSC shall adopt a protocol on how to respond to possible security threats. ${ }^{63}$ Each protocol shall contain several subsequent phases and comply with the specific rules for the use of force suggested by the international shipping industry. ${ }^{64}$ In practice, when a security threat is identified, the team leader has to preventively notify the shipmaster that he intends to initiate the procedures deemed appropriate to deter the pirate attack. Upon the shipmaster's authorisation, the team leader can then adopt non-lethal measures, such as evading maneuvers and warnings that include the use of spotlights, eye-safe lasers, water cannons, and glare rockets. Firearms can also be displayed but not immediately used. Only if these measures are not sufficient to deter the attack, can warning shots be discharged from firearms. The resort to lethal force can only occur upon the specific shipmaster's authorisation.

When the security of vessels and crews is made depending on private personnel, specific provisions are also addressed to the embarkation, transportation, storage, use and disembarkation of firearms. ${ }^{65}$ In addition to the

59. See the Implementing Ministerial Decree, Art. 3

60. See the Implementing Ministerial Decree, Art. 3. These requirements supplement the general conditions applicable to all Italian private security guards stipulated in Art. 256-bis mad Art. 257-bis of the above recalled Royal Decree on private security.

61. See Decree of the Italian Ministry of Interior, 2013.

62. See E. Cusumano and S. Ruzza, 'The Political Cost-Effectiveness of Private Vessel Protection: The Italian Case', Italian Journal of International Affairs, (2018). Available at: https://www.tandfonline.com/doi/abs/ 10.1080/03932729.2018.1450110 (last visited 3 January 2019).

63. See Implementing Ministerial Decree.

64. See Patel (Chairperson of the United Nations Working Group on the use of mercenaries), 'New Forces Need New Rules', in Opinion piece by UN Working Group on the use of mercenaries, 25 September 2012; UN News Center, Somalia: UN experts on use of mercenaries urge greater oversight for private security contractors, 16 December 2012.

65. See Implementing Ministerial Decree, Art. 6. aforementioned authorisations and licenses regarding the use of arms by contractors, the Implementing Ministerial Decree stipulates that the shipowner shall obtain a specific authorisation to carry firearms on board. ${ }^{66}$ The firearms which shall be exclusively used for the deployment of security services that can be embarked either on the Italian territory or on the territory of foreign states which border a High Risk Area. ${ }^{67}$ During the navigation, firearms have to be stored and locked into a specific safe, for which the shipmaster holds the key. Should the vessel be attacked by pirates in international waters, the key shall be given to the ship security officer, who will then, in turn, hand the weapons to the private guards. When firearms are no longer needed, they shall be stored again in the safe, and the key shall be returned to the shipmaster. Moreover, only one firearm per private security guard and no more than two spare ones can be stored on board. The possibility to employ automatic firearms, normally forbidden under Italian law for nonmembers of public security forces, can be decided on a case-by-case basis by the Ministry of Interior. The Commander in Chief of the Italian Navy Fleet and the Italian Foreign Ministry office shall be provided in advance with accurate information about the number and description of firearms, together with the number and nationality of contractors and the route of the vessel. ${ }^{68}$

Making clear when and under what conditions the transit of foreign merchant vessels with antipiracy armed guards on board can occur, the Italian Ministerial Decree seeks to prevent or at least limit any potential prejudice to costal states which may be concerned by the passage of foreign armed vessels. As far as the perspective of the international law of the sea is considered, when armed merchant vessels pass through territorial waters, the flag state must duly take into account additional rules. Article 19 UNCLOS provides that foreign flagged vessels may pass through territorial waters so long as [their passage] is not prejudicial to the peace, good order or security of the coastal state. ${ }^{69}$ Hence, according to this provision, it is plausible that coastal states do not retain innocent the passage of foreign armed ships. Arms, indeed, may easily represent a great risk in terms of potential liability. ${ }^{70}$ However, as seen earlier, the embarkation, transportation, storage, use and disembarkation of firearms are now subject to a certain number of strict Italian regulations. Besides that, according to such regulations when Italian vessels sail through waters

66. See Implementing Ministerial Decree, Art. 6, para. 1.

67. Ibid

68. See Implementing Ministerial Decree.

69. See Art. 14 of the 1958 Convention on the Territorial Sea and the Contiguous Zone and Art. 19 UNCLOS. For doctrine, see G. Cataldi, I/ passaggio delle navi straniere nel mare territoriale (1990), at 97.

70. See MSC.1/Circ.1405/Rev.2, Revised Interim Guidance to Shipowners, Ship Operators and Shipmasters on the Use of Privately Contracted Armed Security Personnel on Board Ships in the High Risk Area. Available at: www.imo.org/en/OurWork/Security/SecDocs/Documents/ Piracy/MSC.1-Circ.1405-Rev2.pdf (last visited 3 January 2019). The IMO's Maritime Security Committee is the highest technical body of the IMO consisting of all Member States. 
belonging to coastal states near the High Risk Area, firearms shall be duly locked and their use shall be expressly forbidden. The same aim is probably behind the implementing provisions which impose a progressive use of force, but only and specifically within dangerous international waters. All these specific prescriptions seem to respect or at least consider the principle on the innocent passage and the principle of the territorial sovereignty of the coastal state provided by the international law of the sea.

The importance to have in force domestic provisions governing the use of private force against piracy suspects respond to another primary need: to find an adequate balance between the use of lethal force and the fundamental right to life prescribed by international human rights law. Namely, the fundamental right to life is not an absolute right, but its application is extremely wide. States are prohibited at all times from arbitrarily depriving any person of his or her life and, accordingly, it cannot be abrogated arbitrarily when, for instance, suspected pirates are captured..$^{71}$ Besides that, the prohibition concerns the taking of life by police, soldiers and any other agents exercising police powers and, thus, also in the case of private security personnel. ${ }^{72}$

Italian implementing provisions requiring the respect of specific conditions and progressive phases on the use of arms on board consider that according to human rights law, in order to be lawful, the use of force must respect the two core law enforcement principles, which are "proportionality" and "necessity'. 73 In particular, according to the first criterion, there must be proportionality between the measure of force used on the one hand and the purpose and interest pursued on the other hand. According to the second criterion, the use of force must be avoided, as far as possible, and, where force is inevitable, it must not go beyond what is reasonable and necessary in the circumstances. ${ }^{74}$

71. For a commentary on the application of the right to life, see D.J. Harris, M.O'Boyle \& C. Warbrick, Law of the European Convention on Human Rights, (2009), at 56; S. Piedimonte Bodini, 'Fighting Maritime Piracy under the European Convention on Human Rights', European journal of international law 5 (2011); J. Callewaerth, 'Is there a Margin of Appreciation in the Application of Arts. 2, 3, and 4 of the Convention?', Human Rights Law Journal 6 (1998); D. Guilfoyle, Counter-Piracy Law Enforcement and Human Rights', 59 International and Comparative Law Quarterly 151 (2010).

72. See, among others, ECtHR, Avsar v. Turky, application No, 25657/94, Judgment of 10 July 2001, definitive on 27 March 2002, para. 37 in Reports of Judgments an Decisions, 2001-VII.

73. See Art. 8-bis, para. 9, of the 1988 Convention for the suppression of unlawful acts of violence against the safety of maritime navigation (SUA Convention), as amended by the 2005 SUA Protocol; The 1979 Code of Conduct for Law Enforcement Officials, adopted by General Assembly Resolution 34/169 of 17 December 1979; The 1995 UN Fish Stocks Agreement for the Implementation of Provisions of the UNCLOS, relating to the Conservation and Management of Straddling Fish Stocks and Highly Migratory Fish Stock, opened to signature in New York on 4 December 1995, 34 ILM (1995) 1547.

74. See S.S: 'I'm Alone', Canada v. United States, Reports of International Arbitration Awards, Vol. 3, p. 1615 and ITLOS, M/V 'Saiga' (No. 2) Case, Saint Vincent and the Grenadines v. Guinea, Judgment of 1 July 1999. See D. Guilfoyle, Shipping Interdiction and the Law of the Sea, Cambridge University Press (2009), at 268.
With specific respect to case of the use of force at sea against alleged pirates, in several resolutions the UNSC affirms that human rights law is applicable also during counter-piracy operations. ${ }^{75}$ Likewise, in May 2012, the IMO's Maritime Security Committee issued a new interim guidance for privately contracted armed security personnel, where it is stated, inter alia, that it should ensure that armed personnel understand that:

[...] all reasonable steps should be taken to avoid the use of force and, if force is used, that force should be used as part of a graduated response plan, in particular including the strict implementation of the latest version of BMP;

$[\ldots]$ the use of force should not exceed what is strictly necessary and reasonable in the circumstances and that care should be taken to minimize damage and injury and to respect and preserve human life; $[\ldots]^{76}$.

On these grounds, we would argue that the adoption of detailed implementing rules governing the gradual use of force reveals, at least on paper, the intention of Italian authorities to enact a system capable to respect pirates' human rights and protect them from potential interference by others, including private security personnel.

\subsection{The Relation between the Master and the Guards}

With respect to the relation between the shipmaster and the security personnel, as with any other private personnel on board, security guards are subject to the authority of the shipmaster, who maintains exclusive control over the vessel. ${ }^{77}$ In particular, according to the Implementing Ministerial Decree, shipmaster and team leader have different tasks and competences. While the shipmaster is the representative of the shipowner on board and has the power to authorise the arming and deployment of the private guards, he cannot really influence the tactical choices of the contractors, who are led and supervised by their team leader. ${ }^{78}$ And as far as the duties of contractors are concerned, they include surveillance, identifying threats, assisting the shipmaster in implementing the appropriate protective measures, preparing the crew for the pirate attack in compliance with the shipping industry's BMPs, and protecting the ship itself. The

75. See, among others, Security Council Resolution 1851, para. 6, supra note 5 .

76. See IMO, 'Interim Guidance to Private Maritime Security Companies Providing Privately Contracted Armed Security Personnel on Board Ships in the High Risk Area', MSC.1/Circ.1443, 25 May 2012, §5.15. It is also argued that companies themselves have a duty to respect fundamental human rights, such as the right to life and the right to freedom from torture. Under the 2008 UN Framework for Business and Human Rights, developed by the UN Special Representative on Business and Human Rights and endorsed by the Human Rights Council in Resolution $8 / 7$ of 18 June 2008 ( $(1)$, there is a corporate responsibility to respect human rights. See also 'Report of the independent international commission of inquiry on the Syrian Arab Republic', UN doc. A/HRC/19/69, 22 February 2012, §106.

77. See Implementing Ministerial Decree, Art. 9 which with respect to the relation between the shipmaster and private guards expressly recalls Arts. 8, 186, 187, 295, 297 and 302 of the Italian Navigation Code.

78. See Implementing Ministerial Decree, Art. 9. 
team leader in particular, is responsible for offering advices to the shipmaster on security matters, conducting security inspections, supervising the activities of the other contractors, and drafting a daily report of their activities. The master, on the other hand, retains the power to order a ceasefire. ${ }^{79}$

Relatively different was the relationship between the shipmaster and the military team leader. Namely, the military team was subject to the authority of the shipmaster, exception made in the event of pirate attacks. In these cases, VPDs were subject to the sole authority and responsibility of the military team leader, who assumed the role of Judicial Police Officer and guided all military team members in accordance with the rules of engagement issued by the Italian Ministry of Defense. The use of lethal force was allowed on the basis of the need to protect the commercial vessel at risk of piracy and felt within the exclusive responsibility of the military team leader. ${ }^{80}$

In light of the differences existing with the military team and provided that private personnel is for the first time allowed on board Italian merchant ships, the adoption of implementing provisions including details on the relation between the shipmaster and the contractors was certainly essential to bring clarity among maritime operators.

\section{Concluding Remarks}

The adoption of a national legal and regulatory system represents an important step forward in the management of the maritime security field. In response to criminality at sea, shipping companies around the world had progressively started to rely on several categories of security services in order to defend ships and crews against piracy attacks. This tendency led to a proliferation of weapons at sea and various types of armed security teams operating aboard private commercial vessels. In the absence of a domestic model of regulation, also Italian shipping companies had started to rely on armed services offered by foreign security companies through the expedient of sailing flags of convenience. Likewise, other European member states, Italian decision-makers understood the need and the relevance of filling the security gap left by international law and regulating the emerging phenomenon.

And whether one likes the idea or not, armed security services on board civilian vessels appear to become an increasingly common feature of counter-piracy tools. Considering that there is not enough naval capacity to secure all pirate-prone hotspots around the world, on a short-term basis the deployment of on-board security services is probably the only way forward to provide ships with sufficient protection and actual freedom of navigation in dangerous international waters. From the

79. Ibid

80. See Law 130, Art. 5, para. 2 data reported in the most recent annual report of the IMB,${ }^{81}$ it emerges that in the period between 2015 and 2016, Italian flagged vessels were never successfully attacked by pirates. Together with such concrete outcomes, the fact that for the protection of their properties, public and private entities ashore may rely also on private personnel since the adoption in 1931 of the Italian Code of Public Security, encourages the idea that national authorities will not turn back for the maritime security field to either a hybrid or a public model of regulation. Moreover, the private security trend is fully consistent with the parallel growing expansion of maritime private security services at international and European level as well as with the general widespread use of security contractors for public security services ashore.

On a long-term basis, however, the Italian model of regulation and, more generally, national regimes governing the use of armed security services at sea will not be sufficient. Under the Italian legal and regulatory system, armed services can gradually use the force on the high seas only. The above recalled respect both of the coastal states sovereignty and principle of innocent passage implies the permanence of a security gap in the territorial waters of several coastal states prone to pirates. Off the Gulf of Guinea, for instance, where commercial ships are attacked especially in territorial waters, the total number of kidnapped crews in 2016 was the highest in ten years. ${ }^{82}$

In light of this persistent security gap and the parallel growth of profitability of the private counter-piracy market, our main idea is to foster the stipulation of bior-multilateral treaties which may directly address the subject of on-board armed protection of vessels. Following the precedent of the bilateral agreements regarding the transfer of piracy suspects captured by naval units operating in the waters off the Horn of Africa, ${ }^{83}$ state parties of the proposed instrument might be all these states which are concerned by maritime piracy and armed robbery at sea. In other words, memoranda of understanding might be stipulated between, on the one hand flag states interested in improving their freedom of navigation also when passing across dangerous territorial waters, and on the other hand, costal states in the regions infested by pirates and interested in disrupting the phenomenon. Well aware of the significant rise in the number of companies offering armed security services and of the lack of harmonisation, the IMO issued, and then revised, interim guidelines which are

81. See the IMB Report on acts of piracy and armed robbery against ships for the period 1 January - 31 December 2016, January 2017, available at: http://lignesdedefense.blogs.ouest-france.fr/files/2016-AnnualIMB-Piracy-Report.pdf (last visited 3 January 2019).

82. Ibid

83. Among others, see Exchange of Letters between the EU and Kenya on the conditions and modalities for the transfer of persons suspected of having committed acts of piracy and detained by the EUNAVFOR, and seized property in the possession of EUNAVFOR, from EUNAVFOR to Kenya and for their treatment after such transfer, OJEU L79/52 (2009); Exchange of Letters between the EU and Seychelles, OJEU L 315/37, (2009); Agreement between the EU and Mauritius, OJEU L 254/3 (2011). 
addressed to all actors in the maritime security field and aim at regulating when, where and how armed force may be used in countering piracy. ${ }^{84}$ Similar non-binding measures were also undertaken by governments with the Monteux Document ${ }^{85}$ and by the international shipping industries with the GUARDCONs and the BMPs. Such measures may be interpreted as a desire to regulate the field. At international level, however, what is still really urgently needed is a binding instrument which is capable to coordinate the different initiatives already undertaken by flag states at the national level in the absence of an explicit discipline on security services.

84. See MSC.1/Circ.1443 on Interim Guidance to private maritime security companies providing contracted armed security personnel on board ships in the High Risk Area; MSC.1/Circ.1408 on Interim recommendations for port and coastal States regarding the use of privately contracted armed security personnel on board ships in the High Risk Area; MSC.1/Circ.1406/Rev.1 on Revised interim recommendations for flag States regarding the use of privately contracted armed security personnel on board ships in the High Risk Area; MSC.1/Circ.1405/Rev.2 on Revised interim guidance to shipowners, ship operators and shipmasters on the use of privately contracted armed security personnel on board ships in the High Risk Area; and a joint MSC and Facilitation Committee circular, Questionnaire on information on port and coastal State requirements related to privately contracted armed security personnel on board ships, which is aimed at gathering information on current requirements.

85. The Monteux Document is the result of an international process launched by the Government of Switzerland and the International Committee of the Red Cross. It was finalised by consensus on 17 September 2008 by seventeen states: Afghanistan, Angola, Australia, Austria, Canada, China, France, Germany, Iraq, Poland, Sierra Leone, South Africa, Sweden, Switzerland, the United Kingdom of Great Britain and Ireland, Ukraine and the United States of America. 